\title{
Stress Relaxation and Thermal Expansion of Aromatic \\ Polyamideimide-Aromatic Polyamide Fiber Composite Films
}

by

\author{
Yoshihiro OHмiYa and Hirotaro Kambe \\ Research Institute of Composite Materials, Faculty of Tech., \\ Gunma Univ., Tenjin-cho, Kiryu, Gunma 376
}

Aromatic Polyamideimide (PAI) films were reinforced by aromatic polyamide fiber as unidirectionally oriented composite (Type 1), bidirectionally oriented laminate composite (Type 2), and bidirectionally oriented cloth composite (Type 3). The stress relaxation and thermal expansion of the composite films were investigated with respect to direction of fiber orientation. The behavior of the unidirectionally oriented composite film was more anisotropic than that of other composite films. In the cloth composite film, the elastic behavior was isotropic. The thermal expansion behavior was isotropic in the laminate composite film. Thus the anisotropy of elasticity of the composite films does not always correspond to that of thermal expansion.

\section{芳香族ポリアミド繊維で強化した 芳香族ポリアミドイミドフィルムの応力緩和と熱膨張}

\author{
近江谷 克 裕・神 戸 博太郎*
}

（原稿受理：1985年 3 月 4 日）

\begin{abstract}
芳香族ポリアミドイミドを芳香族ポリアミド繊維で強化するこ とによって, 高強度, 高耐熱性の織維強化フィルムを作成するこ とができる，この種の絨維強化フィルムに打いて，強化方法を変 えることによって物性がいかに変化するかを, 応力緩和と熱膨張 測定を行って検討した.
\end{abstract}

\section{1. 実}

\section{験}

\section{$1 \cdot 1$ 試 料}

強化材には芳香族ポリアミド繊維 (Du-Pant 社製, Kevlar 49, 195 デニール), マトリックスには芳香族ポリアミトイミド（東 レ製, PAI ワニス)を使用した. 強化方法は, Table 1 に示した 上5に一軸方向強化, 二軸方向積層強化，二軸方向平織布強化の 3 種類である. 繊維強化フィルムは, 強化材に真空中でワニスを

\footnotetext{
* 群馬大学工学部応用複合材料研究施設 $\overline{\mathrm{T}} 376$ 桐生市天神町 $1-$
} $5-1$.
Table 1. Fiber reinforced films.

\begin{tabular}{llc}
\hline Sample & Fiber orientation & Volume percent of fiber \\
\hline Type 1 & unidirectional & $5 \pm 1$ \\
Type 2 & bidirectional (laminate) & $10 \pm 2$ \\
Type 3 & bidirectional (cloth) & $9 \pm 2$ \\
\hline
\end{tabular}

含浸させた後, 常圧, $140^{\circ} \mathrm{C} て ゙ ~ 3$ 時間硬化させ, 残余溶媒を除く

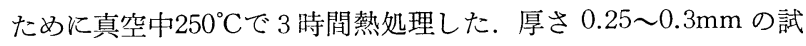
料フィルムを作った。

$\mathbf{1} \cdot \mathbf{2}$ 测 定

応力緩和举動の測定には, 自作の応力緩和測定装置 ${ }^{1)}$ を使用し た. 試験片はすべて幅 $5 \mathrm{~mm}$ の短冊型である. 繊維軸方向に詨し て種々の角度 $\theta$ で試験片を切り出し, 初期長を $25 \mathrm{~mm}$, ひずみを 初期長に対し $0.4 \%$ 与光, 室温, 大気中で測定した. 
熱膨張挙動の測定には, Perkin-Elmer 社製熱機械分析装置 （TMS）を使用した。試料片は幅約 $1 \mathrm{~mm}$, 初期長 $7.75 \mathrm{~mm}$ とし, 応力緩和測定用試料と同じく繊維軸方向に対して種々の配向角で 切り出した。昇温速度 $2.5^{\circ} \mathrm{C} / \mathrm{min}$ ，大気中で測定した。

$$
\text { 2. 結果 }
$$

\section{$2 \cdot 1$ 応力緩和}

Fig. 1，2，3 は，それぞれ Type 1〜3 繊維強化フィルム試料の 応力緩和曲線である. 図中の $\theta$ は, 繊維軸之試料师の切り出し力 向の間の角である。 Тyp= 1 試料は, 繊維軸方向 $\left(\theta=0^{\circ}\right)$ 飞扔い て強化材に支配された高い弾性率と緩和しにくい学動を示し，瀻 維軸方向からのずれの角が大きくなると共に, マトリックスが試 料全体の弾性挙動を支配する程度が大きくなり, 試料の弾性率は 低下し緩和が起こりやすくなる。 $\theta=90^{\circ}$ の試料では, 初期の弾 性挙動はマトリックスに支配され, 時間の経過と共に急激な緩和 が起こる. $\theta=45^{\circ}$ あるいは $67.5^{\circ}$ の試料と比べて，この急激な 緩和は第 3 成分とも言える界面等の影響が現れていることを示す ものと推察される.

Type 2 試料では，二軸方向積層強化されていることで， $\theta=0^{\circ}$ あるいは $90^{\circ}$ の試料の弾性率は，一軸方向強化の $\theta=0^{\circ}$ 試料より 若干低下しているものの，繊維軸方向では高い值を保ち，かつ緩 和しにくい挙動を示している. Type 1 試料のような大きな緩和

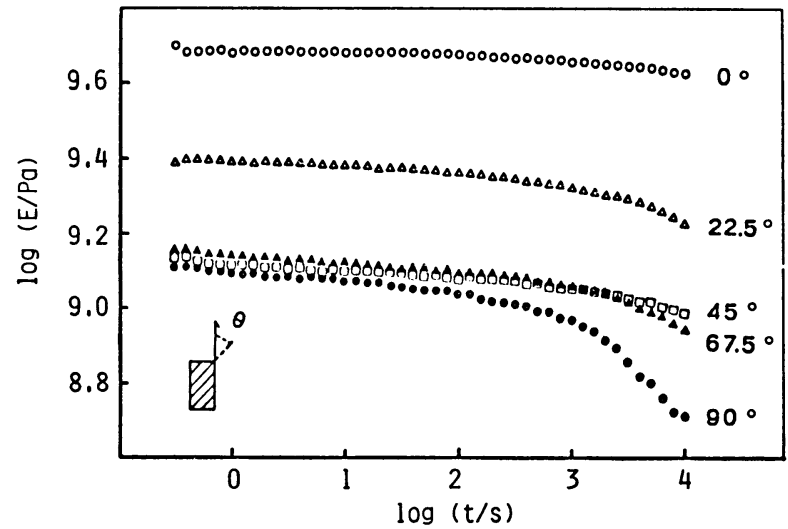

Fig. 1 Relaxation curves for Type 1 sample films cut in various directions $\theta$ to the fiber axis.

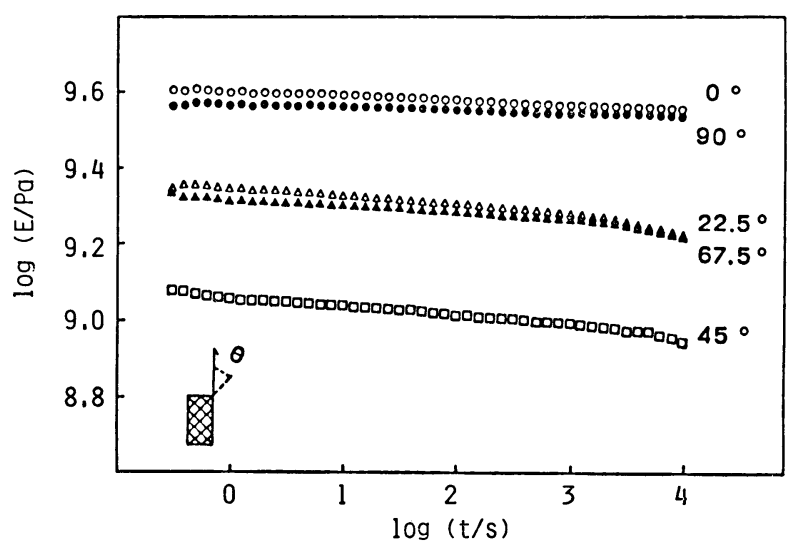

Fig. 2 Relaxation curves for Type 2 sample films cut in various directions $\theta$ to the fiber axis.

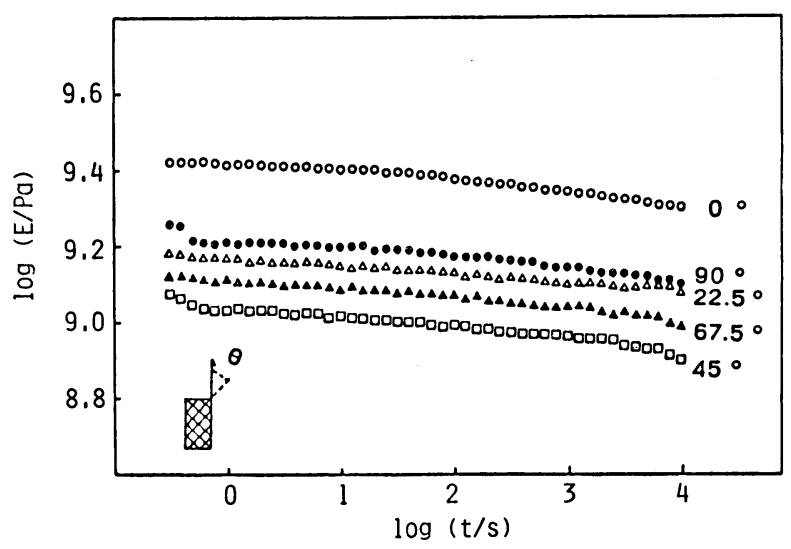

Fig. 3 Relaxation curves for Type 3 sample films cut in various directions $\theta$ to the fiber axis.

は認められないが，依然として $\theta$ の違いによって緩和の起こりや すさが異なり，試料フィルム面内に大きな異方性が存在すること がわかる。

Type 3 試料は平織布で強化しているので, 強化材の弾性特性 は試料フィルムの弾性率に直接反映していない，繊維軸方向に切 り出した試験片の緩和挙動は, 他の方向に切り出した試験片の緩 和挙動とあまり差がなく，また試料の弾性率は $\theta$ の值にかかわら ず，Type 1，2 試料に比べて低下している。 $\theta$ の值により弾性率 のレベルがあまり変わらないことは，Type 3 試料が他の二つの タイプと比較して，より等方的であることを示している。

\section{$2 \cdot 2$ 熱膨張}

Fig. 4，5，6 は，それぞれ Type 1〜3 試料の熱膨張曲線である. 強化材のケブラー緎維は負の膨張 (収縮) $)^{2)}$ を、マリックスの

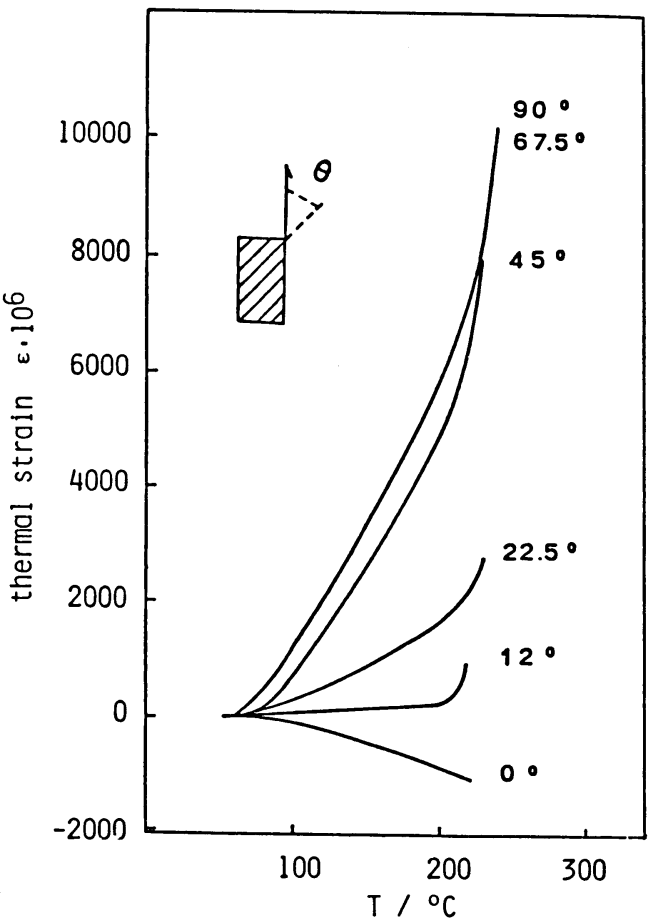

Fig. 4 Dilation curves for Type 1 sample films cut in various directions $\theta$ to the fiber axis. 


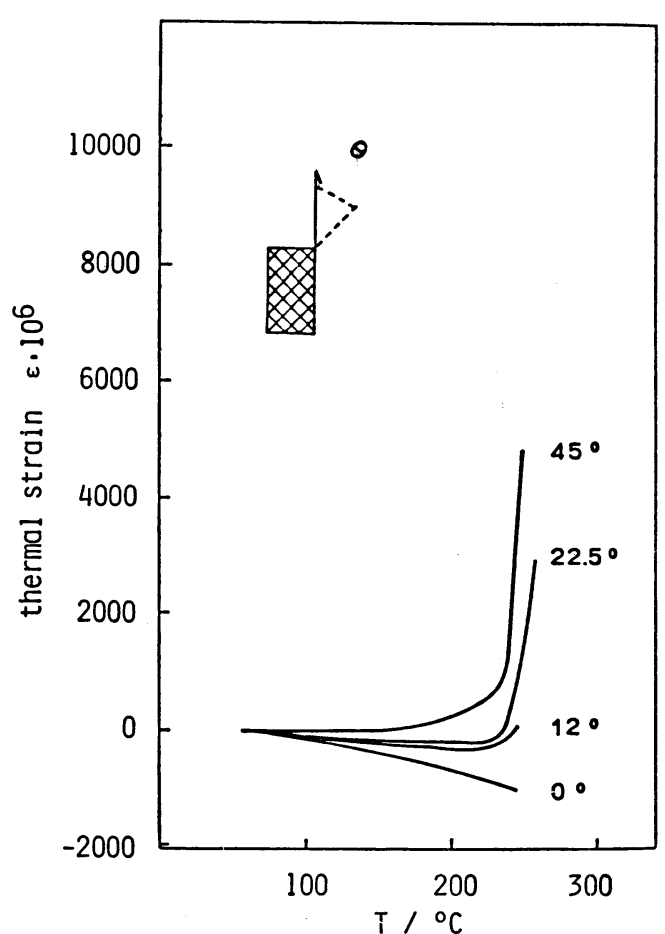

Fig. 5 Dilation curves for Type 2 sample films cut in various directions $\theta$ to the fiber axis.

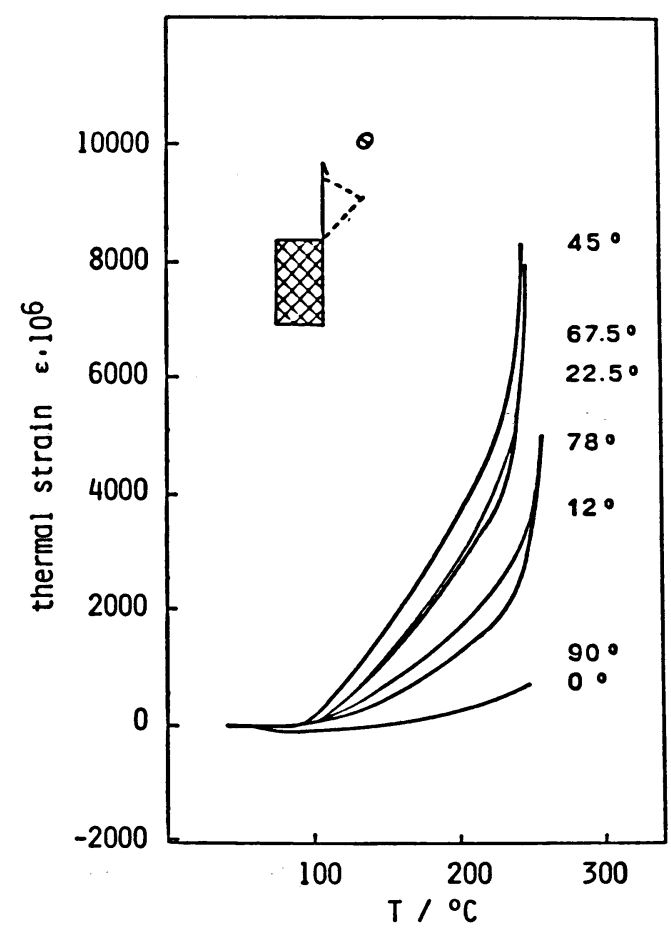

Fig. 6 Dilation curves for Type 3 sample films cut in various directions $\theta$ to the fiber axis.
PAI は正の膨張を示す. Type 1 試料では, 瀻維軸方向 $\left(\theta=0^{\circ}\right)$ に扔いて負の膨張を示すが，䋐維軸方向からのずれの角が大きく なると共に熱膨張が大きくなる。 $\theta=45^{\circ}$ の試料では，マトリッ クスと同程度に熱膨張し， $\theta=90^{\circ}$ に近づくと共に更に大きな熱 膨張を示す、繊維の配向軸に対し横方向の大きい膨張は, 瀻維軸 方向に招いて妨げられているマトリックスの膨張が，横方向に現 れたと考えられる3.

Type 2では, $\theta=0 \sim 22.5^{\circ}$ の試料の膨張は負であるが，これは 直交した強化材によってマトリックスの膨張が一様に妨げられて いることを示している，上に示した Type 1 試料拈よび下に示す Type 3 試料に比べて, Type 2 陚料の膨張は等方的であると言光 る。すなわち, $220^{\circ} \mathrm{C}$ 付近まで膨張は $\theta$ にあまり依存しない。

Type 3 試料では, $\theta$ の值にかかわらず正の膨張を示し，最大 に膨張する $\theta=45^{\circ}$ の試料では, 熱膨張の程度はマトリックスと 同じくらいである. 平織布で強化したとき, 強化材は試料フィル 么の弾性挙動に刘する場合と同様, 熱膨張挙動に刘して支配的な 影響を及注さず，むしろマトリックスの寄与が大きい。また試料 フィルム面内に異方性が生じている.

試料フィルムの $250^{\circ} \mathrm{C}$ 以上に批ける急激な膨張は, すべてマト リックス PAI によるものである. すなわち, マトリックスのガ ラス転移はこの温度域で起こり ${ }^{4)}$, ゴム状態 PAI の大きい膨張係 数がこの挙動に反映されているものと考光られる.

\section{3. 結}

\section{論}

3 種類の芳香族ポリアミド䋐維で強化した芳香族ポリアミドイ ミドフィルムを用い，応力緩和拈よび熱膨張測定を行った結果， 以下の結諭を得た。

i ）一軸方向䋐維強化フィルムでは, 弾性挙動, 熱膨張挙動共に 面内に大きな異方性が存在する，また瀻維軸に対して横方向に おいて，界面等の存在によると思われる影響が現れる。

ii）二軸方向積層強化フィルムでは, 熱膨張挙動が等方的であり, 二軸方向平織布強化フィルムでは, 弾性挙動が等方的である.

iii）複合材料フィルムに扔いて, 弾性挙動の異方性と熱膨張挙動の 異方性は必ずしも対応して現れるものでない.

（昭和59年10月 24 日，第32回レオロジー討論会にて講演）

\section{文献}

1）未発表.

2) Kevlar 49 Data Manual, E.I. DuPont de Nemours \& Co.

3） L.E. ニールセン，小野木重治訳, “高分子と複合材料の力 学的性質”, 化学同人 (1976).

4）横田力男, 秋山昌純, 神户博太郎, 熱測定, 8, 22 (1981). 